\title{
DIFFERENTIAL EFFECTS OF THE DOPAMINE D3 RECEPTOR ANTAGONIST PG01037 ON COCAINE AND METHAMPHETAMINE SELF-ADMINISTRATION IN RHESUS MONKEYS
}

\author{
William S. John ${ }^{1}$, Amy Hauck Newman ${ }^{2}$, and Michael A. Nader ${ }^{1}$ \\ ${ }^{1}$ Department of Physiology and Pharmacology, Wake Forest School of Medicine, Winston-Salem, \\ NC \\ ${ }^{2}$ Medicinal Chemistry Section, Molecular Targets and Medications Discovery Branch, National \\ Institute on Drug Abuse - Intramural Research Program, National Institutes of Health, Baltimore, \\ MD
}

\begin{abstract}
The dopamine $\mathrm{D}_{3}$ receptor $\left(\mathrm{D}_{3} \mathrm{R}\right)$ has been shown to mediate many of the behavioral effects of psychostimulants associated with high abuse potential. This study extended the assessment of the highly selective $\mathrm{D}_{3} \mathrm{R}$ antagonist PG01037 on cocaine and methamphetamine (MA) selfadministration to include a food-drug choice procedure. Eight male rhesus monkeys ( $\mathrm{n}=4$ /group) served as subjects in which complete cocaine and MA dose-response curves were determined daily in each session. When choice was stable, monkeys received acute and five-day treatment of PG01037 (1.0-5.6 mg/kg, i.v.). Acute administration of PG01037 was effective in reallocating choice from cocaine to food and decreasing cocaine intake, however, tolerance developed by day 5 of treatment. Up to doses that disrupted responding, MA choice and intake were not affected by PG01037 treatment. PG01037 decreased total reinforcers earned per session and the behavioral potency was significantly greater on MA-food choice compared to cocaine-food choice. Furthermore, the acute efficacy of PG01037 was correlated with the sensitivity of the $D_{3} / D_{2} R$ agonist quinpirole to elicit yawning. These data suggest (1) that efficacy of $\mathrm{D}_{3} \mathrm{R}$ compounds in decreasing drug choice is greater in subjects with lower $\mathrm{D}_{3} \mathrm{R}$, perhaps suggesting that it is percent occupancy that is the critical variable in determining efficacy and (2) differences in $\mathrm{D}_{3} \mathrm{R}$ activity in chronic cocaine vs. MA users. Although tolerance developed to the effects of PG01037 treatment on cocaine choice, tolerance did not develop to the disruptive effects on food-
\end{abstract}

\footnotetext{
C 2015 Elsevier Ltd. All rights reserved.

Address Correspondence to: Michael A. Nader, Ph.D., Department of Physiology and Pharmacology, Wake Forest University School of Medicine, Medical Center Boulevard, Winston-Salem, NC 27157-1083, Phone: 336-713-7172, Fax: 336-713-7180, mnader@wakehealth.edu.

FINANCIAL DISCLOSURES

The authors declare no conflicts of interest. AUTHOR CONTRIBUTIONS

W.S.J. and M.A.N. designed the experiments. W.S.J. performed the behavioral studies, and analyzed the data. A.H.N oversaw the synthesis of PG01037. The manuscript was written by W.S.J., A.H.N. and M.A.N.

Publisher's Disclaimer: This is a PDF file of an unedited manuscript that has been accepted for publication. As a service to our customers we are providing this early version of the manuscript. The manuscript will undergo copyediting, typesetting, and review of the resulting proof before it is published in its final citable form. Please note that during the production process errors may be discovered which could affect the content, and all legal disclaimers that apply to the journal pertain.
} 
maintained responding. These findings suggest that combination treatments that decrease cocaineinduced elevations in DA may enhance the efficacy of $D_{3} R$ antagonists on cocaine selfadministration.

\section{Keywords}

cocaine; methamphetamine; dopamine $\mathrm{D}_{3}$ receptors; PG01037; self-administration; rhesus monkeys

\section{INTRODUCTION}

Recent estimates indicate that the economic cost of drug addiction in the U.S. is over $\$ 500$ billion (cf. O'Connor et al., 2014). Considering that there are no FDA approved treatments for psychostimulant addiction, identifying viable neuropharmacological targets is a goal of preclinical research. Given the recognized importance of dopamine (DA) mechanisms in psychostimulant addiction, compounds that modulate DA neurotransmission have been investigated as possible treatment strategies. In particular, the $D A D_{3}$ receptor $\left(D_{3} R\right)$ has emerged as a possible candidate among the DA D2-like receptor family. In contrast to the $\mathrm{D}_{2} \mathrm{R}$ subtype, the $\mathrm{D}_{3} \mathrm{R}$ is apparently upregulated following chronic stimulant abuse. For instance, postmortem studies of cocaine overdose victims have demonstrated that $\mathrm{D}_{3} \mathrm{R}$ densities are higher in the ventral striatum compared to aged-matched controls (Staley and Mash, 1996; Segal et al., 1997). More recently, PET studies utilizing the $\mathrm{D}_{3} \mathrm{R}$-preferring ligand PHNO ([ $\left.{ }^{11} \mathrm{C}\right]-(+)-$ propyl-hexahydro-naphtho-oxazin) showed significantly higher

$\mathrm{D}_{3} \mathrm{R}$ availability in cocaine-dependent individuals (Payer et al., 2013; Matuskey et al., 2014) as well as methamphetamine (MA) polydrug abusers (Boileau et al., 2012) compared to control subjects. Even further contributing to the $\mathrm{D}_{3} \mathrm{R}$ as a potential pharmacotherapeutic target is its restricted neuroanatomical localization in the mesolimbic DA system, an area of the brain implicated in mediating the reinforcing effects of psychostimulant drugs (Sokoloff et al., 1990; Levant, 1997). As a result, compounds selective for the $\mathrm{D}_{3} \mathrm{R}$ may affect drugmotivated behavior while being relatively free of extrapyramidal side effects hence providing a preferred therapeutic target.

There is also strong behavioral evidence supporting the role of the $\mathrm{D}_{3} \mathrm{R}$ in mediating the effects of psychostimulants. For instance, initial studies demonstrated dose-dependent reductions in cocaine self-administration by various $\mathrm{D}_{3} \mathrm{R}$ agonists (Caine and Koob, 1993; Caine et al., 1997), perhaps in an additive manner. However, $\mathrm{D}_{3} \mathrm{R}$ agonists can function as reinforcers and possess cocaine-like discriminative stimulus effects (e.g., Lamas et al., 1996; Nader and Mach, 1996; Sinnott et al., 1999; Collins and Woods, 2007; Baladi et al., 2014) decreasing the likelihood of their use as pharmacotherapies for addiction. On the other hand, $\mathrm{D}_{3} \mathrm{R}$ antagonists or partial agonists may be the more desirable treatment strategy because these compounds likely lack abuse liability (Newman et al., 2005, 2012). $\mathrm{D}_{3} \mathrm{R}$-preferring antagonists or partial agonists have been shown to attenuate cocaine's discriminative stimulus, priming, and reinforcing effects, although accumulating data suggest that many of these results are species dependent (Keck et al., under review). For instance, the $\mathrm{D}_{3} \mathrm{R}$ selective antagonist NGB2904 (56-fold $\mathrm{D}_{3}$ vs. $\mathrm{D}_{2}$ ) decreased cocaine self-administration under a progressive-ratio (PR) schedule of reinforcement, as well as cue-, and drug-induced 
reinstatement in rats (Gilbert et al., 2005; Xi et al., 2006; Xi and Gardner, 2007), but did not attenuate the discriminative stimulus or reinforcing effects of cocaine in monkeys (Martelle et al., 2007). Since then, additional analogues have been developed to improve $D_{3} R$ affinity, selectivity, and bioavailability (Heidbreder and Newman, 2010). For example, the novel olefinic analogue $\mathrm{PG} 01037$ is a potent $\left(\mathrm{hD}_{3} \mathrm{R}\right.$ and $\mathrm{hD}_{2} \mathrm{R} \mathrm{Ki}=0.7$ and $93.3 \mathrm{nM}$, respectively) and selective (>100-fold) $\mathrm{D}_{3} \mathrm{R}$ antagonist (Grundt et al., 2005, 2007). PG01037 has been shown to decrease MA self-administration under a PR schedule of reinforcement (Higley et al., 2010; Orio et al., 2010) and cue-induced reinstatement in rats (Higley et al., 2010) and unlike NGB2904, attenuated the discriminative stimulus effects of cocaine and cocaineinduced reinstatement in monkeys, but was ineffective against cocaine self-administration under a second-order schedule of reinforcement (Achat-Mendes et al., 2010).

In addition to species differences, different schedules of reinforcement may also contribute to variable results with $D_{3} R$ compounds. For instance, many studies have evaluated $D_{3} R$ compounds using second-order and PR schedules of reinforcement. Although responding under these reinforcement schedules appears to be more sensitive to the effects of $D_{3} R$ compounds, many of these reports have also observed nonselective decreases in responding for alternative reinforcers under two-component multiple schedules of food and cocaine presentation (e.g., Claytor et al., 2006; Martelle et al., 2007). These non-selective effects make it difficult to determine if $\mathrm{D}_{3} \mathrm{R}$ antagonists are decreasing the reinforcing effects of cocaine and food or if the drug is disrupting all operant responding. Thus, the first goal of the present study was to extend the evaluation of PG01037 on cocaine and MA selfadministration to include non-drug responding under conditions in which disruptions in reinforcing effects could be distinguished from overall disruptions in operant responding. For these studies, we utilized a food-drug choice paradigm in which complete cocaine or MA dose-response curves were determined in each session (Negus, 2003). Addiction can be conceptualized as a choice disorder (Heyman, 2009; Banks and Negus, 2012), so animal studies using drug vs. non-drug choice behavior may have the greatest face validity to the human condition and would most effectively facilitate translation of results to clinical settings (Haney and Spealman, 2008; Hutsell et al., 2015). The clinical translation of drug effects on behavior was also pursued in the present study by comparing the acute and repeated (5-day) effects of PG01037 on self-administration. In the present study, when PG01037 was administered for 5 consecutive days, self-administration only occurred on days 1 and 5 of treatment to better model the human condition in which periods of abstinence may occur between access to cocaine or MA.

Further, individual differences involving $\mathrm{D}_{2} / \mathrm{D}_{3} \mathrm{R}$ availability and drug history may play a role in differential sensitivity to $\mathrm{D}_{3} \mathrm{R}$ compounds (Czoty and Nader, 2013; Martelle et al., 2014). A behavioral assay that has been used to characterize $D_{3} R$ and $D_{2} R$ function is quinpirole-elicited yawning and hypothermia, respectively (Collins et al., 2005, 2007). Quinpirole is a $D_{3} / D_{2} R$ agonist and the unconditioned behavior of yawning is sensitive to drug dose, pharmacological manipulations (Collins et al., 2007) and chronic drug history (Hamilton et al., 2010; Martelle et al., 2014). In fact, significant differences in potency of quinpirole was noted in monkeys with a MA history compared to a cocaine history (Martelle et al., 2014), providing an important rationale for studying $D_{3} R$ antagonists in monkeys with different stimulant histories. Another goal of the present study was to use quinpirole-elicited 
yawning and hypothermia as unconditioned behaviors to further investigate the relationship between $D_{3} R$ and $D_{2} R$ sensitivity and the efficacy of PG01037 on cocaine and MA choice. The investigation of individual differences between treatment responders and nonresponders could provide important information regarding individualized pharmacotherapeutic strategies.

\section{MATERIALS AND METHODS}

\subsection{Subjects}

Eight adult male rhesus monkeys (Macaca mulatta), with extensive cocaine or MA selfadministration histories (Martelle et al., 2014; John et al. in press) served as subjects (Table 1). All monkeys were fitted with aluminum collars and trained to sit in a primate restraint chair (Primate Products, Redwood City, CA). Monkeys were individually housed in stainless-steel cages with visual and auditory contact with each other, ad libitum access to water in their home cage, and fed sufficient standard laboratory chow (Purina LabDiet 5045, St Louis, Missouri, USA) to maintain body weights at approximately $98 \%$ of free-feeding weights. Environmental enrichment was provided as outlined in the Animal Care and Use Committee of Wake Forest University Non-Human Primate Environmental Enrichment Plan. Experimental procedures as well as animal housing and handling were performed in accordance with the 2011 National Research Council Guidelines for the Care and Use of Mammals in Neuroscience and Behavioral Research and were approved by the Animal Care and Use Committee of Wake Forest University.

\subsection{Surgery}

All monkeys were surgically prepared with a chronic indwelling intravenous catheter and subcutaneous vascular access port (VAP; Access Technologies, Skokie, IL) under aseptic conditions. An antibiotic (30 mg/kg of kefzol, i.m.; cefazolin sodium; Marsam Pharamaceuticals, Inc., Cherry Hill, NJ) was administered 1 hour prior to surgery. Monkeys were initially anesthetized with ketamine $(15 \mathrm{mg} / \mathrm{kg}$, i.m.) and maintained with ketamine supplements. A catheter was inserted into a major vein (femoral or internal or external jugular) to the level of the posterior vena cava. The distal end of the catheter was passed subcutaneously to an incision made slightly off the midline of the back and attached to a VAP, which was placed in a pocket formed by blunt dissection. After surgery, an analgesic dose of Metacam (meloxicam; $0.1 \mathrm{mg} / \mathrm{kg}$, i.m.) was administered SID for three days.

\subsection{Quinpirole-elicited yawning and hypothermia}

Prior to the start of the present study, cumulative quinpirole dose-response curves were determined in each monkey. On the day of testing, monkeys were taken from the home cage, placed in a primate restraint chair, and transported to a quiet procedure room with a video camera. They were then habituated to the room for 5 minutes. Monkeys first received an i.m. injection of saline $(1.0 \mathrm{ml} / 10 \mathrm{~kg})$ followed 30 minutes later by ascending cumulative doses of quinpirole $(0.01,0.03,0.1,0.3 \mathrm{mg} / \mathrm{kg} ; \mathrm{i} . \mathrm{m}$.). Yawns were recorded immediately after each injection for 30 minutes and defined as a full extension of the jaws, withdrawal of lips, and exposure of teeth (Code and Tang, 1991). Core body temperature was taken by rectal thermometer immediately after the monkey habituated to the room and 30 minutes after each 
injection. Two observers blind to the experimental conditions scored videos in which the inter-observer variability was $<5 \%$. Some of these data were shown as group means in Martelle et al. (2014).

\subsection{Apparatus}

All behavioral studies were conducted in ventilated, sound-attenuating chambers $(1.5 \times 0.74$ x 0.76 m; Med Associates, St. Albans, VT). Each chamber was equipped with an operant panel that contained two photo-optic switches (Model 117-1007; Stewart Ergonomics, Inc., Furlong, PA) located on each side of the panel with a horizontal row of three stimulus lights positioned $14 \mathrm{~cm}$ above each switch. The switches were positioned to be within easy reach of the monkey seated in the primate chair. A food receptacle, above which was a red stimulus light, was located between the photo-optic switches and connected with a Tygon tube to a pellet dispenser (Med Associates) located on the top of the chamber for delivery of 1-g banana-flavored food pellets (Bio-Serv, Frenchtown, NJ). A peristaltic infusion pump (Cole-Parmer Instrument Co., Niles, IL), located on top of the chamber, was used for delivering drugs at a rate of approximately $1.5 \mathrm{ml} / 10 \mathrm{~s}$.

Before each session, the area on the back of the animal containing the vascular access port was cleaned with chlorhexidine and isopropyl alcohol swabs (Prevantics ${ }^{\mathrm{TM}}$, Orangeburg, NY). A 22-guage Huber Point Needle (Access Technologies) was inserted into the port, which connected the venous catheter to the infusion pump. The pump was operated for approximately $3 \mathrm{~s}$ to fill the port with the concentration of drug available during the experimental session. Pretreatment drug administration was given outside the chamber immediately before the session and the monkey was placed into the operant chamber. After each session, catheters were flushed with heparinized saline $(100 \mathrm{U} / \mathrm{ml})$ to prevent clotting.

\subsection{Food-drug choice}

For these studies, food availability was signaled by illumination of a green light above the appropriate switch while different doses of cocaine or MA were signaled by illumination of different combinations of lights above the switch and the houselight. The multiple concurrent schedule consisted of 5 components in which monkeys chose between food pellets and ascending unit doses of cocaine or MA (i.e., no injection, 0.003, 0.01, 0.03 and $0.1 \mathrm{mg} / \mathrm{kg}$ per injection) by using different discriminative stimuli. The drug dose was varied by manipulating the pump duration and consequently the volume delivered (see Czoty and Nader, 2013; John et al., in press). Thus, a complete dose-effect curve was determined in each monkey each session, typically 5 days per week. Assignment of the food or drugassociated switch was counterbalanced across monkeys. Components were separated by a 5min timeout (TO) period. Each component ended when 10 total reinforcers had been earned (food and drug injections) or 20 minutes had elapsed, whichever came first. If 10 reinforcers were earned before the $20 \mathrm{~min}$ component ended, the component TO was added to the remainder of the component time, so each session was $2 \mathrm{hrs}$ in duration. If a response was emitted on the alternate switch before an FR was completed, the response requirement on the first switch was reset. Delivery of a drug reinforcer was accompanied by illumination of the red light in the center of the response panel, above the food receptacle, during an injection. Following the delivery of each reinforcer (food or drug) there was a 30 second 
timeout (TO) period during which all lights remained off and responding had no scheduled consequences.

Ratio requirements for food and drug were adjusted for each monkey such that allocation of responding to the drug switch increased over the session as the available dose of cocaine and MA increased (Table 1). There was not a significant difference in ratio values between selfadministration groups according to an unpaired t-test $(p=0.32)$. Responding was considered stable when $\mathcal{2} 0 \%$ of reinforcers were earned on the drug switch when the alternative to food was no injection (component 1 ) and $0.003 \mathrm{mg} / \mathrm{kg}$ per injection cocaine/MA (component 2) and $\geq 80 \%$ of reinforcers were earned on the drug switch when the alternative to food was $0.03 \mathrm{mg} / \mathrm{kg}$ per injection cocaine/MA (component 4) or $0.1 \mathrm{mg} / \mathrm{kg}$ per injection cocaine/MA (component 5). This criterion had to be met for 3 consecutive days before a drug treatment was administered.

Once responding was stable, acute doses of PG01037 (1.0-5.6 mg/kg) were administered intravenously immediately before the self-administration session. Doses were tested typically twice per week, with at least 2 days between test sessions. The effect of each acute dose was double determined. After completing the PG01037 dose-response curve, the highest acute dose that produced a decrease in choice of at least $25 \%$ in the last component was administered intravenously for five consecutive sessions. If no dose decreased choice, the highest dose tested without substantial disruptive effects, defined as a reduction of total trials by greater than $50 \%$, was administered intravenously for five consecutive sessions. For the five day treatment, self-administration only occurred on days 1 and 5 of treatment and on days 2-4, PG01037 was administered prior to sessions in which only component 1 (food alone) was available.

\subsection{Data analysis}

For each monkey, the total number of yawns at each of the five 30-minute bins, representing saline and different quinpirole doses, was determined. $\mathrm{An}^{\mathrm{ED}_{50}}$ was determined for each monkey using the ascending limb of the quinpirole-elicited yawning dose-response curve. For each dose, quinpirole-induced hypothermia was determined by the difference in core body temperature 30 minutes post injection compared to the core body temperature measured 30 minutes after the vehicle injection. $\mathrm{An}^{\mathrm{ED}_{50}}$ was determined using the descending limb of the quinpirole-induced hypothermia dose-response curve. In the selfadministration studies, the primary dependent variable was percent drug choice defined as: (number of FRs completed on the drug-associated switch $\div$ total number of FRs completed)*100. Percent drug choice was plotted as a function of cocaine or MA dose and the last 3 days prior to the start of PG01037 treatment were averaged and served as baseline. Acute PG01037 dose-effect curves were the average of two determinations. Chronic PG01037 was shown as single determinations on Day 1 and Day 5 (when complete choice sessions were conducted). Drug choice dose-effect curves were analyzed using two-way repeated-measures ANOVA with cocaine or MA dose and treatment as the main factors. A significant ANOVA was followed by multiple comparisons post-hoc tests to compare test conditions with baseline conditions. For the cocaine group, data were averaged between two high doses: for three monkeys, $5.6 \mathrm{mg} / \mathrm{kg}$ PG01037 was the dose used in the analysis, while 
$3.0 \mathrm{mg} / \mathrm{kg}$ was the dose for one monkey. In the latter monkey, $5.6 \mathrm{mg} / \mathrm{kg}$ PG01037 completely eliminated responding. Additional dependent variables collected during each session included total food reinforcers total drug reinforcers, total reinforcers per session and drug intake per session. These data were analyzed using a repeated measures one-way ANOVA across treatment drug conditions followed by the Dunnett post hoc test. The criterion for significance was set a priori at the $95 \%$ level of confidence $(p<0.05)$ in all cases. To correlate quinpirole-elicited yawning and hypothermia with the effects of PG01037 on drug choice, the latter effects were quantified by subtracting the area under the $\%$ choice curve after treatment from baseline. Separate Pearson correlation analyses were used to examine the relationship between PG01037 efficacy at decreasing cocaine and MA choice (i.e., area under the curve) and $\mathrm{ED}_{50}$ values quinpirole-elicited yawning and quinpirole-induced hypothermia. All analyses were conducted with Prism 6 for Mac OS X software (Graphpad Software, Inc.).

2.7. Drugs

$(-)$ Cocaine $\mathrm{HCl}$ and (+)methamphetamine were supplied by the National Institute on Drug Abuse (Bethesda, MD) and dissolved in sterile 0.9\% saline. PG01037 was synthesized as described in Grundt et al. (2005) in the Medicinal Chemistry Section, National Institute on Drug Abuse-Intramural Research Program (Baltimore, MD) and dissolved in 10\% betacyclodextrin and sterile water. Heat and sonication were used for solubility purposes and all drug solutions were passed through a sterile $0.2-\mu \mathrm{m}$ filter (Milipore Inc) for intravenous administration.

\section{RESULTS}

\subsection{Quinpirole-elicited Yawning in Food-Cocaine and Food-MA Choice Monkeys}

Table 2 shows the total number of yawns at each quinpirole dose and the $\mathrm{ED}_{50}$ value for monkeys with cocaine and MA histories. For 2 of the 4 cocaine monkeys, peak yawns occurred following the highest quinpirole dose $(0.3 \mathrm{mg} / \mathrm{kg})$, while peak yawns in 3 of $4 \mathrm{MA}$ monkeys occurred following a dose $1.5 \log$-units lower $(0.01 \mathrm{mg} / \mathrm{kg})$. Table 2 also shows the $\mathrm{ED}_{50}$ values for quinpirole-induced hypothermia for monkeys with cocaine and MA histories. There was a main effect of quinpirole dose $[\mathrm{F}(4,30)=9.82, p<0.0001]$, but not a significant main effect of group (cocaine and MA) or an interaction. These data were used to phenotypically characterize each monkey prior to the start of PG01037 treatment and to determine if there was a relationship between quinpirole $\mathrm{ED}_{50}$ dose and sensitivity to the acute effects of PG01037 on drug self-administration (see below).

\subsection{Effects of Acute PG01037 on Food-Cocaine Choice}

Under baseline conditions, monkeys exclusively chose food when the alternative was only food or a low dose of cocaine $(0.003 \mathrm{mg} / \mathrm{kg})$ and exclusively reallocated their behavior and chose cocaine when higher doses $(0.03-0.1 \mathrm{mg} / \mathrm{kg})$ were available (Fig. 1A, filled squares). For the group, the maximum number of trials was obtained in each component, except the $5^{\text {th }}$ component (Fig. 1B). This was represented as a decrease in food choices (Fig. 1C) and an increase in cocaine choices (Fig. 1D) across the session. In two of the four monkeys, all 10 trials per component were completed across the session; for the other two monkeys, less 
than 6 of 10 trials were completed at the highest cocaine dose (see Fig. S1). For the group, monkeys obtained near the maximum number of reinforcers available during the entire session ( $46.5 \pm 2.4$ out of 50; Fig. 1E) and average total session intake was $1.05 \pm 0.2 \mathrm{mg} / \mathrm{kg}$ (Fig. 1F).

Acute administration of PG01037 (1.0-5.6 mg/kg) decreased choice of higher cocaine doses in three (R-1688, R-1689, R-1692) of four monkeys (Fig. S1). For three of the four monkeys, the "best dose" was $5.6 \mathrm{mg} / \mathrm{kg}$ PG01037; monkey (R-1692) demonstrated a higher degree of sensitivity to this dose, as reflected by a $>50 \%$ reduction in total trials completed. For the safety of the animal, testing of this dose was discontinued and the next highest dose tested, $3.0 \mathrm{mg} / \mathrm{kg}$, was included in group-averaged analysis. Two-way repeated measures ANOVA on mean percent cocaine choice (Fig. 1A) demonstrated a significant main effect of cocaine dose $[\mathrm{F}(4,12)=14.66, p<0.001]$ and a significant cocaine dose and PG01037 treatment interaction $[\mathrm{F}(8,18)=4.6, p<0.01]$. Post hoc analysis indicated a significant decrease in percent choice of both 0.03 and $0.1 \mathrm{mg} / \mathrm{kg}$ cocaine $(\mathrm{p}<0.05)$ following acute PG01037 administration (Fig. 1A, open symbols). Consistent with the changes in percent cocaine choice, acute PG01037 treatment resulted in a significant reallocation of responding from cocaine to food (Fig. 1C and D, open symbols), and significant reductions in total reinforcers (Fig. 1E, open symbol) and cocaine intake (Fig. 1F, open symbol).

\subsubsection{Effects of Repeated PG01037 on Food-Cocaine Choice-When PG01037} was administered for five consecutive days with self-administration only occurring on days one and five of treatment, tolerance developed to the acute PG01037 reduction in cocaine choice by day five (Fig. 1A, gray symbols). Only one monkey (R-1692) out of four demonstrated a substantial reallocation from drug to food choice from both acute and 5-day treatment (Fig. S1). Interestingly, this monkey appeared to have the lowest sensitivity to quinpirole-induced yawning $\left(\mathrm{ED}_{50}=0.17\right.$, Table 2). Comparing acute and 5-day PG01037 data, there was a significant main effect of cocaine dose for total reinforcers per component $[\mathrm{F}(4,12)=5.6, p<0.01$; Fig. 1B], food reinforcers $[\mathrm{F}(4,12)=3.5, p<0.05$; Fig. $1 \mathrm{C}]$ and cocaine injections $[\mathrm{F}(3,9)=5.7, p<0.05$; Fig. 1D] and a significant main effect of PG01037 treatment for total reinforcers $[\mathrm{F}(2,6)=16.5, p<0.01$; Fig. 1B]. There was a significant interaction between cocaine dose and PG01037 treatment for total reinforcers $[\mathrm{F}(8,24)=6.2, p<0.001]$, food reinforcers $[\mathrm{F}(8,24)=9.54, p<0.0001]$, and a trend towards significance for cocaine injections $[\mathrm{F}(6,18)=2.6, p=0.054]$. Post hoc analysis revealed that both acute and 5-day PG01037 treatment significantly decreased total reinforcers earned early in the session, however, there was a recovery to baseline levels by the last two components (Fig. 1B). For cocaine intake, repeated-measures one way ANOVA demonstrated a main effect of PG01037 treatment $[\mathrm{F}(2,6)=8.8, p<0.05]$, and post-hoc analysis revealed that acute, but not repeated, treatment significantly decreased intake from baseline (Fig. 1F, $p<0.05$ ). Tolerance to the disruptive effects of PG01037 on foodmaintained responding did not develop over five days (Fig. 1C).

\subsection{Effects of Acute PG01037 on Food-Methamphetamine Choice}

Similar to cocaine, under baseline conditions, monkeys exclusively chose food when the alternative was only food or a low dose of MA $(0.003 \mathrm{mg} / \mathrm{kg})$ and exclusively reallocated 
their behavior and chose MA when higher doses $(0.03-0.1 \mathrm{mg} / \mathrm{kg}$ ) were available (Fig. 2A, filled symbols). For the group, the maximum number of trials was obtained in each component, except the $5^{\text {th }}$ component (Fig. 2B). This was represented as a decrease in food choices (Fig. 2C) and an increase in cocaine choices (Fig. 2D) across the session. For all monkeys, the number of trials completed at the highest MA dose was less than 10 (Fig. S2). Compared to the cocaine group, MA monkeys earned fewer total reinforcers during the entire session ( $43.8 \pm 0.6$ out of 50 ; Fig. $2 \mathrm{E})$ and average total session intake was $0.8 \pm 0.06$ $\mathrm{mg} / \mathrm{kg}$ (Fig. 2F), which was also lower than total cocaine intake (Fig. 1F).

Acute administration of PG01037 resulted in variable effects on MA choice (Fig. S2), increasing (R-1691), decreasing (R-1567), producing biphasic effects (R-1693) or no effect (R-1690). Due to the individual-subject variability, acute PG01037 treatment did not significantly alter MA choice from baseline conditions (Fig 2A, open symbols). Post-hoc tests showed that acute PG01037 (1.7 mg/kg) significantly reduced total trials (Fig. 2B), and total food reinforcers (Fig. 2C) in the second component ( $0.003 \mathrm{mg} / \mathrm{kg} \mathrm{MA})$, without affecting the number of MA injections across the session (Fig. 2D). Acute PG01037 did not significantly affect the total reinforcers earned during the session (Fig. 2E, open symbol) or MA intake (Fig. 2F, open symbol).

\subsubsection{Effects of Repeated PG01037 on Food-Methamphetamine Choice-}

Following 5-day PG01037 treatment, MA choice was not significantly altered (Fig. 2A, gray symbols), however, there was a one log-unit rightward shift in the dose-effect curve for one monkey (R-1693; Fig. S2). There was a significant main effect of MA dose on food reinforcers $(\mathrm{F}(4,12)=18.95, p<0.0001$; Fig. $2 \mathrm{C})$ and injections $(\mathrm{F}(3,9)=23.3, p<0.001$; Fig. 2D), a main effect of PG01037 treatment for total reinforcers $(\mathrm{F}(2,6)=8.4, p<0.05$; Fig. 2B), and a significant MA dose and PG01037 interaction for food reinforcers $[F(8,24)$ $=2.7, p<0.05$; Fig. $2 \mathrm{C}]$. One-way repeated-measures ANOVA on total reinforcers earned per session revealed a significant main effect of PG01037 treatment $[\mathrm{F}(2,6)=8.4, p<0.05]$ and a significant decrease compared to baseline only after day 5 of treatment (Fig. 2E, $p<$ 0.05), further demonstrating an enhanced reduction in behavior during repeated PG01037 treatment. Sensitization also occurred to the effects on food reinforcers in which decreases by component were greater on day 5 of treatment compared to day 1 (Fig. 2C). While 5-day treatment with PG01037 significantly decreased total reinforcers per session (Fig. 2E), there was no effect on total MA intake (Fig. 2F).

\subsection{Behavioral potency of PG01037}

To better determine whether acute doses of PG01037 were differentially sensitive to cocaine-, MA- or food-maintained responding, the effect (\% baseline) on mean numbers of total (Fig. 3A), food (Fig. 3B) and drug (Fig. 3C) reinforcers earned during each session for cocaine (open symbols) and MA (closed symbols) monkeys was examined. One-way repeated measures ANOVA performed on raw data indicated a significant main effect of treatment on total reinforcers for both the cocaine $[\mathrm{F}(3,8)=10.46, \mathrm{p}<0.01]$ and $\mathrm{MA}[\mathrm{F}(3,9)$ $=20.9, \mathrm{p}<0.001]$ self-administration groups. Post-hoc analysis revealed that the dose that significantly decreased total reinforcers in the MA group was one-half log-unit lower than the dose required to significantly decrease total reinforcers for the cocaine group (Fig. 3A). 
Further, the dose that significantly decreased total reinforcers in the MA group (3.0 mg/kg) produced a much larger percent decrease from baseline than the dose $(5.6 \mathrm{mg} / \mathrm{kg})$ that significantly decreased total reinforcers in the cocaine group ( 80 vs. $45 \%$ decrease, respectively). Qualitatively, the dose-related effects of PG01037 on total food reinforcers per session were similar to that on total reinforcers. One-way repeated measures ANOVA demonstrated a significant main effect of treatment for the cocaine $[\mathrm{F}(3,8)=4.4, \mathrm{p}<0.05)$ and MA group $[\mathrm{F}(3,9)=6.94, \mathrm{p}<0.05]$. Post-hoc analysis revealed that $3.0 \mathrm{mg} / \mathrm{kg}$ PG01037 produced a significant decrease from baseline in the MA group and $5.6 \mathrm{mg} / \mathrm{kg}$ PG01037 in the cocaine group, a one-half log unit dose lower for the MA group (Fig. 3B). For injections earned per session, PG01037 produced a dose-dependent decrease in the MA group in which one-way repeated measures ANOVA demonstrated a significant main effect of treatment $[F(3,9)=6.03, p<0.05)$ and significant decrease from baseline for $3.0 \mathrm{mg} / \mathrm{kg}$ PG01037 whereas there was no main effect nor significant change from baseline at any individual dose for the cocaine group (Fig. 3C).

\subsection{Correlation Between $D_{3} R$ Sensitivity and PG01037 Efficacy}

Quinpirole-elicited yawning ( $E D_{50}$ values for each monkey) was used to characterize $\mathrm{D}_{3} \mathrm{R}$ sensitivity (see Table 2), while acute PG01037 efficacy was quantified by subtracting the area under the $\%$ choice curve after treatment from baseline (Figs. 1A and 2A). Thus, a positive difference in $\mathrm{AUC}_{\text {baseline }}$ and $\mathrm{AUC}_{+} \mathrm{PG}_{01037}$ indicates PG01037 shifted the cocaine or MA dose-response curve to the right, while a negative difference indicates leftward shifts in the cocaine or MA dose-response curves by PG01037 (see Fig. 4). Collapsing across selfadministration groups (Fig. 4), there was a significant correlation between $\mathrm{ED}_{50}$ and PG01037 efficacy $(r=0.95, p<0.001)$, implying that PG01037 was more effective at reducing drug choice in animals that were less sensitive (represented by the higher $\mathrm{ED}_{50}$ value) to quinpirole-elicited yawning. Collapsing across self-administration groups, there was not a significant correlation between the $\mathrm{ED}_{50}$ value for quinpirole-induced hypothermia and efficacy of PG01037 to alter drug choice $(r=0.005, p=0.99$; data not shown).

\section{DISCUSSION}

The primary objective of the present study was to extend the evaluation of the novel $D_{3} R$ selective antagonist PG01037 on cocaine and MA self-administration to include a food-drug choice procedure in rhesus monkeys. When administered acutely to monkeys choosing between cocaine and food, PG01037 significantly decreased the choice of high doses of cocaine and overall intake. When PG01037 was administered for 5 consecutive days with self-administration only occurring on days 1 and 5 of treatment, tolerance developed to the acute effects on choice and intake. In contrast, acute administration of PG01037 did not alter MA choice or intake, nor did 5-day treatment, up to doses that disrupted total trials completed. A second aim of the present study was to characterize the individual differences in PG01037 efficacy. Potency of quinpirole to elicit yawning, but not hypothermia, was significantly correlated with acute PG01037 efficacy to reduce drug choice implicating $\mathrm{D}_{3} \mathrm{R}$. The third main finding of this study demonstrated the influence that drug history can have on the in vivo effects of $\mathrm{D}_{3} \mathrm{R}$ antagonism. Specifically, the behavioral potency of PG01037 
was higher in monkeys with a history of MA self-administration compared to monkeys with a history of cocaine self-administration, such that PG01037 did not significantly decrease MA choice relative to food up to doses that disrupted all responding.

The preclinical evaluation of acute dose-response curves for various treatment compounds is necessary for the elucidation of receptor mechanisms involved in psychostimulant abuse. In the present study, we compared the behavioral effects of the highly selective $\mathrm{D}_{3} \mathrm{R}$ antagonist PG01037 in monkeys self-administering cocaine to monkeys self-administering MA under similar experimental conditions. While MA, like cocaine, has been shown to function as a reinforcer in rats and monkeys under similar conditions (Stefanski et al., 1999, 2002; Kitamura et al., 2006; Wang and Woolverton, 2007; Wee et al., 2007) and elevate synaptic levels of DA by blocking reuptake (in addition to vesicular release), MA also displays many pharmacokinetic and pharmacodynamic differences. A recent retrospective population-based assessment reported differences in long-term consequences of MA use compared to cocaine use (Curtin et al., 2015). As it relates to developing pharmacotherapeutic treatments, these molecular differences are extremely important (Elkashef et al., 2007) and are exemplified in the present study with the effects of PG01037 on MA vs. cocaine self-administration. For instance, acute administration of PG01037 significantly decreased cocaine choice while not affecting MA choice. One reason for this effect could involve the larger increases in extracellular DA elicited by MA compared to cocaine (Camp et al., 1994; Zhang et al., 2001) that may function to counteract $D_{3} R$ antagonism. Thus, the self-administration of drugs that increase nucleus accumbens DA to a lesser degree than cocaine and MA, like nicotine, may be the most sensitive to $D_{3} R$ blockade. Although selective $D_{3} R$ antagonists have been shown to attenuate the response to nicotine conditioned stimuli and nicotine- and cue-induced reinstatement of nicotine seeking in rats (Andreoli et al., 2003; Khaled et al., 2010; Le Foll et al., 2003, 2005) and reduce cigarette craving in humans (Mugnaini et al., 2013), additional self-administration experiments will be needed to test this hypothesis. Further studies are also needed to better understand the relationship between the efficacy of $\mathrm{D}_{3} \mathrm{R}$ antagonism and the neuropharmacology of other drugs of abuse.

In the present study, there was a positive relationship between $\mathrm{ED}_{50}$ values for quinpirole to elicit yawns and the efficacy of PG01037 to decrease drug choice. As reported earlier, quinpirole was more potent in eliciting yawning in MA-exposed monkeys compared to cocaine-exposed monkeys (Martelle et al., 2014). However, subjects that were less sensitive to quinpirole-elicited yawning demonstrated a greater decrease in drug choice by acute administration of PG01037 and this reached statistical significance in monkeys selfadministering cocaine. Considering the ascending limb of quinpirole-induced yawning is $\mathrm{D}_{3} \mathrm{R}$-mediated and the descending limb is $\mathrm{D}_{2} \mathrm{R}$-mediated (Collins et al., 2005, 2007), it is possible that subjects with larger quinpirole $\mathrm{ED}_{50}$ values have lower $\mathrm{D}_{3} \mathrm{R}$ density/sensitivity and/or higher $\mathrm{D}_{2} \mathrm{R}$ density/sensitivity. However, there was no relationship between $\mathrm{ED}_{50}$ values for quinpirole-elicited hypothermia and the efficacy of PG01037 to decrease drug choice, which implies that the relationship with yawning is a $\mathrm{D}_{3} \mathrm{R}$-selective mechanism. A lack of difference between individuals in quinpirole-induced hypothermia could also be used to rule out any possible pharmacokinetic mechanisms explaining the individual differences in quinpirole potency to elicit yawning. These findings highlight the importance of individual differences and phenotypic characteristics in treatment efficacy. 
High and sustained $\mathrm{D}_{3} \mathrm{R}$ occupancy levels have been demonstrated to be a marker of efficacy for $\mathrm{D}_{3} \mathrm{R}$ antagonists in preclinical and clinical studies (Mugnaini et al., 2013; Kim et al., 2014). Therefore, the animals in the present study with lower $\mathrm{D}_{3} \mathrm{R}$ levels (implied by larger quinpirole yawning $\mathrm{ED}_{50}$ values) may have been able to obtain high $\mathrm{D}_{3} \mathrm{R}$ occupancy levels with PG01037 that were necessary to decrease drug choice. These findings further support the role of using brain $\mathrm{D}_{3} \mathrm{R}$ occupancy levels to predict the efficacy of $\mathrm{D}_{3} \mathrm{R}$ antagonists for the treatment of addiction. Certainly, a better understanding of individual differences and biomarkers to therapeutic response can aid in personalizing pharmacotherapeutic treatments.

There are several possible reasons for the differential behavioral sensitivity to $\mathrm{D}_{3} \mathrm{R}$-selective compounds in monkeys self-administering cocaine vs. MA. Imaging studies have shown that the $\mathrm{D}_{3} \mathrm{R}$ are higher (Prayer et al., 2014; Boileau et al., 2012) and the $\mathrm{D}_{2} \mathrm{R}$ are lower (Volkow et al., 1990, 2001; Nader et al., 2006; Prayer et al., 2014) following both chronic cocaine and MA exposure, although it is not possible to directly compare the magnitude of the differences between studies. While the magnitude of change between $D_{2} R$ and $D_{3} R$ availability and density could be different following chronic cocaine vs. MA exposure, differences in $\mathrm{D}_{2} / \mathrm{D}_{3} \mathrm{R}$ sensitivity may be the more likely mechanism, especially considering there were significant differences in the efficacy of quinpirole to elicit yawns between groups, with MA monkeys being more sensitive to quinpirole (Martelle et al., 2014). In addition, other mechanisms involving neurochemical changes elicited by cocaine and MA may be responsible for the differential behavioral potency of $\mathrm{D}_{3} \mathrm{R}$ compounds. For instance, chronic cocaine and MA exposure have been shown to produce opposite effects on DA transporter (DAT) density (Letchworth et al., 2001; Chu et al., 2008; Groman et al., 2013). As a result, differences in dopaminergic tone may play a role in the postsynaptic responses mediated by $\mathrm{D}_{3}$ Rs. Overexpression of DAT and DAT-knockout studies in transgenic mice illustrate the role of DAT in mediating postsynaptic $\mathrm{D}_{2} / \mathrm{D}_{3} \mathrm{R}$ adaptations and signaling and support this hypothesis. It has been shown that reductions in DAT, similar to what would be expected in MA-exposed animals, resulted in increased levels of $\mathrm{D}_{3} \mathrm{Rs}$ and decreased levels of $\mathrm{D}_{2}$ Rs (Giros et al., 1996; Fauchey et al., 2000), while increased DAT expression, similar to what would be expected in cocaine-exposed animals, produce the opposite changes (Ghisi et al., 2009). Further research is warranted to determine how long-term exposure to cocaine and MA differentially affect neurobiology and how these differences may be incorporated into pharmacotherapeutic treatment strategies. If the sensitivity to quinpirole shown in Fig. 4 does represent low $\mathrm{D}_{3} \mathrm{R} /$ high $\mathrm{D}_{2} \mathrm{R}$ densities, then it may be possible to pharmacologically alter receptor measures (e.g., Stanwood et al., 2000) prior to initiating treatment with PG01037. Such information may lead to the development of combination treatments in which one drug alters DA concentrations, which would enhance the effects of $D_{3} R$ antagonists.

We extended the characterization of PG01037 on food-drug choice to include 5-day treatments in which cocaine or MA was available only on days 1 and 5. Repeated drug effects on behavior are most relevant to a compound's ultimate clinical utility, allowing for the assessment of whether tolerance or sensitization develops to the behavioral effects of the compound. While the reinforcing effects of cocaine were attenuated following acute administration of PG01037, these effects were not sustained by day 5 of treatment. One 
possible reason for the development of tolerance to the acute effects may involve the ratedecreasing effects of PG01037. Although acute PG01037 administration produced significant reductions in cocaine choice and intake, it also significantly reduced total trials and food reinforcement early in the session. Notably, a robust and persistent decrease in food-maintained behavior remained during sessions in which only the food component was available (days 2-4) and total trials were still significantly decreased on day 5 of treatment. These findings suggest that factors previously considered less important to the primary dependent variable of drug-choice compared to simple schedules of reinforcement (i.e., ratedecreasing effects) may impact the assessment of reinforcing efficacy using food-drug choice paradigms (Woolverton and Balster, 1981; Negus, 2003; Czoty and Nader, 2013).

Altogether the present results indicate that the $\mathrm{D}_{3} \mathrm{R}$ may be a viable target for the treatment of psychostimulant abuse because of the significant decreases in cocaine choice following acute administration of PG01037 demonstrated in this study. However, going forward, it will be pertinent to better understand the mechanism for tolerance/sensitization following chronic treatment with $\mathrm{D}_{3} \mathrm{R}$ antagonists for clinical application (see Winhusen et al., 2014 and John et al., in press). These data also highlight that the individual efficacy of $\mathrm{D}_{3} \mathrm{R}$ antagonism is related to $D_{2} / D_{3} R$ sensitivity and drug history. Thus, it should be emphasized that pre-existing differences in $\mathrm{D}_{2} / \mathrm{D}_{3}$ receptors not only underlie the reinforcing effects of psychostimulants (e.g., Vokow et al., 1999; Morgan et al., 2002), but also treatment responses to drugs that target $D_{2} R$ and $D_{3} R$. The investigation of individual differences between treatment responders and non-responders could provide important information regarding individualized pharmacotherapeutic strategies. Future treatment strategies should seek to incorporate these individual differences in order to maximize efficacy.

\section{Supplementary Material}

Refer to Web version on PubMed Central for supplementary material.

\section{Acknowledgments}

We would like to thank Michelle Bell for excellent technical assistance working with the monkeys, J. Cao for the synthesis of PG01037 and Dr. Paul Czoty for statistical consultation. This research was supported by the National Institute on Drug Abuse grant DA012460 and NIDA-IRP. WS John is supported by T32 AA-007565.

\section{References}

Achat-Mendes C, Grundt P, Cao J, Platt DM, Newman AH, Spealman RD. Dopamine D3 and D2 receptor mechanisms in the abuse-related behavioral effects of cocaine: studies with preferential antagonists in squirrel monkeys. J Pharmacol Exp Ther. 2010; 334:556-565. [PubMed: 20494958]

Andreoli M, Tessari M, Pilla M, Valerio E, et al. Selective antagonism at dopamine $\mathrm{D}_{3}$ receptors prevents nicotine-triggered relapse to nicotine-seeking behavior. Neuropsychopharmacol. 2003; 28:1272-1280.

Baladi MG, Newman AH, France CP. Feeding condition and the relative contribution of different dopamine receptor subtypes to the discriminative stimulus effects of cocaine in rats. Psychopharmacol. 2014; 231:581-591.

Banks ML, Negus SS. Preclinical determinants of drug choice under concurrent schedules of drug selfadministration. Adv Pharmacol Sci. 2012:281768. [PubMed: 23243420]

Boileau I, Payer D, Houle S, Behzadi A, Rusjan PM, Tong J, Wilkins D, Selby P, George TP, Zack M, Furukawa Y, McCluskey T, Wilson AA, Kish SJ. Higher binding of the dopamine $\mathrm{D}_{3}$ receptor- 


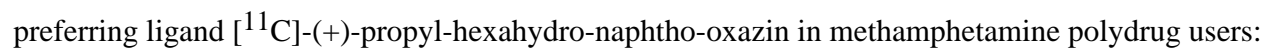
A positron emission tomography study. J Neurosci. 2012; 32:1353-1359. [PubMed: 22279219]

Caine SB, Koob GF. Modulation of cocaine self-administration in the rat through D-3 dopamine receptors. Science. 1993; 260:1814-1816. [PubMed: 8099761]

Caine SB, Koob GF, Parsons LH, Everitt BJ, Schwartz J-C, Sokoloff P. D 3 receptor test in vitro predicts decreased cocaine self-administration in rats. Neuroreport. 1997; 8:2373-2377. [PubMed: 9243643]

Camp DM, Browman KE, Robinson TE. The effects of methamphetamine and cocaine on motor behavior and extracellular dopamine in the ventral striatum of Lewis versus Fischer 344 rats. Brain Res. 1994; 668:180-193. [PubMed: 7704604]

Chu PW, Seferian KS, Birdsall E, Truong JG, Riordan JA, Metcalf CS, Hanson GR, Fleckenstein AE. Differential regional effects of methamphetamine on dopamine transport. Eur J Pharmacol. 2008; 590:105-110. [PubMed: 18599036]

Claytor R, Lile JA, Nader MA. The effects of eticlopride and the selective D3-antagonist PNU 99194A on food- and cocaine-maintained responding in rhesus monkeys. Pharmacol Biochem Behav. 2006; 83:456-464. [PubMed: 16631246]

Code RA, Tang AH. Yawning produced by dopamine agonists in rhesus monkeys. Eur J Pharmacol. 1991; 201:235-238. [PubMed: 1686760]

Collins GT, Witkin JM, Newman AH, Svensson KA, Grundt P, Cao J, Woods JH. Dopamine agonistinduced yawning in rats: a dopamine D3 receptor-mediated behavior. J Pharmacol Exp Ther. 2005; 314:310-319. [PubMed: 15833897]

Collins GT, Newman AH, Grundt P, Rice KC, Husbands SM, Chauvignac C, Chen J, Wang S, Woods JH. Yawning and hypothermia in rats: effects of dopamine D3 and D2 agonists and antagonists. Psychopharmacol. 2007; 193:159-170.

Collins GT, Woods JH. Drug and reinforcement history as determinants of the response-maintaining effects of quinpirole in the rat. J Pharmacol Exp Ther. 2007; 323:599-605. [PubMed: 17675585]

Curtin K, Fleckenstein AE, Robison RJ, Crookston MJ, Smith KR, Hanson GR. Methamphetamine/ amphetamine abuse and risk of Parkinson's disease in Utah: A population-based assessment. Drug Alcohol Dep. 2015; 146:30-38.

Czoty PW, Nader MA. Effects of dopamine D2/D3 receptor ligands on food-cocaine choice in socially housed male cynomolgus monkeys. J Pharmacol Exp Ther. 2013; 344:329-338. [PubMed: 23211363]

Elkashef A, Biswas J, Acri JB, Vocci F. Biotechnology and the treatment of addictive disorders. BioDrugs. 2007; 21:259-267. [PubMed: 17628123]

Fauchey V, Jaber M, Caron MG, Bloch B, Le Moine C. Differential regulation of the dopamine D1, D2 and D3 receptor gene expression and changes in the phenotype of the striatal neurons in mice lacking the dopamine transporter. Eur J Neurosci. 2000; 12:19-26. [PubMed: 10651856]

Ghisi V, Ramsey AJ, Masri B, Gainetdinov RR, Caron MG, Salahpour A. Reduced D2-mediated signaling activity and trans-synaptic upregulation of D1 and D2 dopamine receptors in mice overexpressing the dopamine transporter. Cell Signal. 2009; 21:87-94. [PubMed: 18929645]

Gilbert JG, Newman AH, Gardner EL, Ashby CR Jr, Heidbreder CA, Pak AC, Peng XQ, Xi ZX. Acute administration of SB-277011A, NGB 2904, or BP 897 inhibits cocaine cue-induced reinstatement of drug-seeking behavior in rats: role of dopamine D3 receptors. Synapse. 2005; 57:17, e28. [PubMed: 15858839]

Giros B, Jaber M, Jones SR, Wightman RM, Caron MG. Hyperlocomotion and indifference to cocaine and amphetamine in mice lacking the dopamine transporter. Nature. 1996; 379:606-612. [PubMed: 8628395]

Groman SM, Morales AM, Lee B, London ED, Jentsch JD. Methamphetamine- induced increases in putamen gray matter associate with inhibitory control. Psychopharmacology (Berl). 2013; 229:527-538. [PubMed: 23748383]

Grundt P, Carlsson EE, Cao J, Bennett CJ, McElveen E, Taylor M. Novel heterocyclic trans olefin analogues of $\mathrm{N}$-\{4- [4-(2,3-dichlorophenyl)piperazin-1-yl]butyl\} arylcaroxamides as selective probes with high affinity for the dopamine D3 receptor. J Med Chem. 2005; 48:839-884. [PubMed: 15689168] 
Grundt P, Prevatt KM, Cao J, Taylor J, Floresca CZ, Choi JK, Jenkins BG, Luedtke RR, Newman AH. Heterocyclic analogues of $N$-(4-(4-(2,3-dichlorophenyl)piperazin-1-yl)-butyl)-aryl-carboxamides with functionalized linking chains as novel dopamine D3 receptor ligands: Potential substance abuse therapeutic agents. J Med Chem. 2007; 50:4135-4146. [PubMed: 17672446]

Hamilton LR, Czoty PW, Gage HD, Nader MA. Characterization of the dopamine receptor system in adult rhesus monkeys exposed to cocaine throughout gestation. Psychopharmacology. 2010; 210:481-488. [PubMed: 20401746]

Haney M, Spealman RD. Controversies in translational research: drug self-administration. Psychopharmacology. 2008; 199:403-419. [PubMed: 18283437]

Heidbreder CA, Newman AH. Current perspectives on selective dopamine D3 receptor antagonists as pharmacotherapeutics for addictions and related disorders. Ann NY Acad Sci. 2010; 1187:4-34. [PubMed: 20201845]

Heyman, GH. Addiction: A disorder of choice. Cambridge: Harvard University Press; 2009.

Higley AE, Spiller K, Grundt P, Newman AH, Kiefer SW, Xi ZX. PG01037, a novel dopamine D3 receptor antagonist, inhibits the effects of methamphetamine in rats. J Psychopharmacol. 2011; 25:263-273. [PubMed: 20142301]

Hutsell BA, Negus SS, Banks ML. A generalized matching law analysis of cocaine vs. food choice in rhesus monkeys: Effects of candidate "agonist-based" medications on sensitivity to reinforcement. Drug Alcohol Dep. 2015; 146:52-60.

John WS, Banala AK, Newman AH, Nader MA. Effects of buspirone and the dopamine D3 receptor compound PG 619 on cocaine and methamphetamine self-administration in rhesus monkeys using the food-drug choice paradigm. Psychopharmacology. 2014 In press.

Keck T, John WS, Nader MA, Newman AH. Journal of Medicinal Chemistry. 2014 Under review.

Khaled MA, Farid Araki K, Li B, Coen KM, Marinelli PW, Varga J, Gaál J, Le Foll B. The selective dopamine D3 receptor antagonist SB 277011-A, but not the partial agonist BP 897, blocks cueinduced reinstatement of nicotine-seeking. Int J Neuropsychopharmacol. 2010; 13:181-190. [PubMed: 19995481]

Kim SW, Fowler JS, Skolnick P, Muench L, Kang Y, Shea C, Logan J, Kim D, Carter P, King P, Alexoff D, Volkow ND. Therapeutic doses of buspirone block D3 receptors in the living primate brain. Int J Neuropsychopharmacol. 2014; 17:1257-1267. [PubMed: 24679922]

Kitamura O, Wee S, Specio SE, Koob GF, Pulvirenti L. Escalation of methamphetamine selfadministration in rats: a dose-effect function. Psychopharmacology. 2006; 186:48-53. [PubMed: 16552556]

Lamas X, Negus SS, Nader MA, Mello NK. Effects of the putative dopamine D3 receptor agonist 7$\mathrm{OH}-\mathrm{DPAT}$ in rhesus monkeys trained to discriminate cocaine from saline. Psychopharmacology. 1996; 124:306-314. [PubMed: 8739545]

Le Foll B, Schwartz JC, Sokoloff P. Disruption of nicotine conditioning by dopamine $\mathrm{D}_{3}$ receptor ligands. Mol Psychiatry. 2003; 8:225-230. [PubMed: 12610655]

Le Foll B, Sokoloff P, Stark H, Goldberg SR. Dopamine D3 receptor ligands block nicotine-induced conditioned place preferences through a mechanism that does not involve discriminative-stimulus or antidepressant-like effects. Neuropsychopharmacology. 2005; 30:720-730. [PubMed: 15562293]

Letchworth SR, Nader MA, Smith HR, Vinsant SL, Moore RJ, Friedman DP, Porrino LJ. Cocaine selfadministration in rhesus monkeys: progression of changes in dopamine transporter binding site density. J Neurosci. 2001; 21:2799-2807. [PubMed: 11306632]

Levant B. The D-3 dopamine receptor: neurobiology and potential clinical relevance. Pharmacol Rev. 1997; 49:231-252. [PubMed: 9311022]

Martelle JL, Claytor R, Ross JT, Newman AH, Nader MA. Effects of two novel D3-selective compounds, NGB 2904 and CJB 090, on the reinforcing and discriminative stimulus effects of cocaine in rhesus monkeys. J Pharmacol Exp Ther. 2007; 321:573-582. [PubMed: 17272677]

Martelle SE, Nader SH, Czoty PW, John WS, Duke AN, Garg PK, Garg S, Newman AH, Nader MA. Further characterization of quinpirole-elicited yawning as a model of dopamine D3 receptor activation in male and female monkeys. J Pharmacol Exp Ther. 2014; 350:205-11. [PubMed: 24876234] 
Matuskey D, Gallezot JD, Pittman B, Williams W, Wanyiri J, Gaiser E, Lee DE, Hannestad J, Lim K, Zheng MQ, Lin SF, Labaree D, Potenza MN, Carson RE, Malison RT, Ding YS. Dopamine $\mathrm{D}_{3}$ receptor alterations in cocaine-dependent humans imaged with $\left[{ }^{11} \mathrm{C}\right](+)$ PHNO. Drug Alcohol Depend. 2014; 139:100-105. [PubMed: 24717909]

Morgan D, Grant KA, Gage HD, Mach RH, Kaplan JR, Prioleau O, Nader SH, Buchheimer N, Ehrenkaufer RL, Nader MA. Social dominance in monkeys: dopamine $\mathrm{D}_{2}$ receptors and cocaine self-administration. Nature Neuroscience. 2001; 5:169-174.

Mugnaini M, Iavarone L, Cavallini P, Griffante C, Oliosi B, Savoia C, Beaver J, Rabiner EA, Micheli F, Heidbreder C, Andorn A, Merlo Pich E, Bani M. Occupancy of brain dopamine D3 receptors and drug craving: a translational approach. Neuropsychopharmacology. 2013; 38:302-12. [PubMed: 22968817]

Nader MA, Mach RH. The reinforcing effects of the putative dopamine $\mathrm{D}_{3}$ agonist 7-OH-DPAT in rhesus monkeys: Effects of cocaine self-administration history. Psychopharmacology. 1996; 125:13-22. [PubMed: 8724444]

Nader MA, Morgan D, Gage HD, Nader SH, Calhoun T, Buchheimer N, Ehrenkaufer R, Mach RH. PET imaging of dopamine $\mathrm{D} 2$ receptors during chronic cocaine self-administration in monkeys. Nature Neurosci. 2006; 9:1050-1056. [PubMed: 16829955]

Negus SS. Rapid assessment of choice between cocaine and food in rhesus monkeys: effects of environmental manipulations and treatment with d-amphetamine and flupenthixol. Neuropsychopharmacology. 2003; 28:919-931. [PubMed: 12637948]

Newman AH, Grundt P, Nader MA. Dopamine D3 receptor partial agonists and antagonists as potential drug abuse therapeutic agents. J Med Chem. 2005; 48:3664-3679.

Newman AH, Blaylock BL, Nader MA, Bergman J, Sibley DR, Skolnick P. Medication discovery for addiction: translating the dopamine D3 receptor hypothesis. Biochem Pharmacol. 2012; 84:882890. [PubMed: 22781742]

O'Connor PG, Sokol RJ, D'Onofrio G. Addiction medicine: The birth of a new discipline. JAMA Intern Med. 2014 in press.

Orio L, Wee S, Newman AH, Pulvirenti L, Koob GF. The dopamine D3 receptor partial agonist CJB090 and antagonist PG01037 decrease progressive ratio responding for methamphetamine in rats with extended-access. Addiction Biol. 2010; 15:312-323.

Payer DE, Behzadi A, Kish SJ, Houle S, Wilson AA, Rusjan PM, Tong J, Selby P, George TP, McCluskey T, Boileau I. Heightened $\mathrm{D}_{3}$ dopamine receptor levels in cocaine dependence and contributions to the addiction behavioral phenotype: A positron emission tomography study with [ $\left.{ }^{11} \mathrm{C}\right]-(+)-P H N O$. Neuropsychopharmacology. 2013; 39:311-8. [PubMed: 23921256]

Payer DE, Balasubramaniam G, Boileau I. What is the role of the $\mathrm{D}_{3}$ receptor in addiction? A mini review of PET studies with [(11)C]-(+)-PHNO. Prog. Neuro-Psychopharmacol. Biol. Psychiatry. 2014; 52:4-8.

Segal DM, Moraes CT, Mash DC. Up-regulation of $\mathrm{D}_{3}$ dopamine receptor mRNA in the nucleus accumbens of human cocaine fatalities. Brain Res Mol Brain Res 1997. 1997; 45:335-9.

Sinnott RS, Mach RH, Nader MA. The role of dopamine $\mathrm{D}_{3}$ receptors in the reinforcing and discriminative stimulus effects of cocaine in rhesus monkeys. Drug Alcohol Dep. 1999; 54:97110.

Sokoloff P, Giros B, Martres MP, Bouthenet ML, Schwartz JC. Molecular cloning and characterization of a novel dopamine receptor $\mathrm{D}_{3}$ as a target for neuroleptics. Nature. 1990; 347:146-51. [PubMed: 1975644]

Soto PL, Katz JL. Interactions of cocaine with dopamine D2-like antagonists in squirrel monkeys. Psychopharmacol. 2013; 226:393-400.

Staley JK, Mash DC. Adaptive increase in $\mathrm{D}_{3}$ dopamine receptors in the brain reward circuits of human cocaine fatalities. J Neurosci. 1996; 16:6100-6106. [PubMed: 8815892]

Stanwood GD, Lucki I, McGonigle P. Differential regulation of dopamine D2 and D3 receptors by chronic drug treatment. J Pharmacol Exp Ther. 2000; 295:1232-1240. [PubMed: 11082460]

Stefanski R, Ladenheim B, Lee SH, Cadet JL, Goldberg SR. Neuroadaptations in the dopaminergic system after active self-administration but not after passive administration of methamphetamine. Eur J Pharmacol. 1999; 371:123-135. [PubMed: 10357249] 
Stefanski R, Lee SH, Yasar S, Cadet JL, Goldberg SR. Lack of persistent changes in the dopaminergic system of rats withdrawn from methamphetamine self-administration. Eur J Pharmacol. 2002; 439:59-68. [PubMed: 11937093]

Volkow ND, Fowler JS, Wolf AP, Schlyer D, Shiue CY, Alpert R, Dewey SL, Logan J, Bendriem B, Christman D, Hitzemann R, Henn G. Effects of chronic cocaine abuse on postsynaptic dopamine receptors. Am J Psychiatry. 1990; 147:719-724. [PubMed: 2343913]

Volkow ND, Chang L, Wang GJ, Fowler JS, Ding YS, Sedler M, Logan J, Franceschi D, Gatley J, Hitzemann R, et al. Low level of brain dopamine D2 receptors in methamphetamine abusers: association with metabolism in the orbitofrontal cortex. Am J Psychiatry. 2001; 158:2015-2021. [PubMed: 11729018]

Wang Z, Woolverton WL. Estimating the relative reinforcing strength of ( \pm )-3,4methylenedioxymethamphetamine (MDMA) and its isomers in rhesus monkeys: comparison to (+)-methamphetamine. Psychopharmacology. 2007; 189:483-488. [PubMed: 17063335]

Wee S, Wang Z, Woolverton WL, Pulvirenti L, Koob GF. Effect of aripiprazole, a partial D2 receptor agonist, on increased rate of methamphetamine self-administration in rats with prolonged access. Neuropsychopharmacology. 2007; 32:2238-2247. [PubMed: 17327886]

Winhusen TM, Kropp F, Lindblad R, Douaihy A, Haynes L, Hodgkins C, Chartier K, Kampman KM, Sharma G, Lewis DF, VanVeldhuisen P, Theobald J, May J, Brigham GS. Multisite, randomized, double-blind, placebo-controlled pilot clinical trial to evaluate the efficacy of buspirone as a relapse-prevention treatment for cocaine dependence. J Clin Psychiatry. 2014; 75:757-64. [PubMed: 24911028]

Witkin JM, Schindler CW, Tella SR, Goldberg SR. Interaction of haloperidol and SCH 23390 with cocaine and dopamine receptor subtype-selective agonists on schedule-controlled behavior of squirrel monkeys. Psychopharmacology. 1991; 104:425-431. [PubMed: 1838199]

Woolverton WL, Balster RL. Effects of antipsychotic compounds in rhesus monkeys given a choice between cocaine and food. Drug Alcohol Dep. 1981; 8:69-78.

Xi ZX, Gardner EL. Pharmacological actions of NGB 2904, a selective dopamine D3 receptor antagonist, in animal models of drug addiction. CNS Drug Reviews. 2007; 13:240-259. [PubMed: 17627675]

Xi ZX, Newman AH, Gilbert JG, Pak AC, Peng XQ, Ashby CR Jr, Gitajn L, Gardner EL. The novel dopamine D3 receptor antagonist NGB 2904 inhibits cocaine's rewarding effects and cocaineinduced reinstatement of drug-seeking behavior in rats. Neuropsychopharmacology. 2006; 31:1393-405. [PubMed: 16205781]

Zhang Y, Loonam TM, Noailles PA, Angulo JA. Comparison of cocaine and methamphetamineevoked dopamine and glutamate overflow in somatodendritic and terminal field regions of the rat brain during acute, chronic, and early withdrawal conditions. Ann NY Acad Sci. 2001; 937:93120. [PubMed: 11458542] 


\section{Highlights}

- Dopamine $\mathrm{D}_{3}$ receptors $\left(\mathrm{D}_{3} \mathrm{R}\right)$ mediate many behavioral effects of psychostimulants

- $\quad$ PG01037, a $\mathrm{D}_{3} \mathrm{R}$ antagonist, decreased cocaine but not methamphetamine reinforcement

- PG01037 effects correlated with an unconditioned behavior elicited by quinpirole

- Tolerance developed to the positive effects of PG01037 on cocaine choice

- The findings suggest $D_{3} R$ antagonists are more efficacious in certain phenotypes 

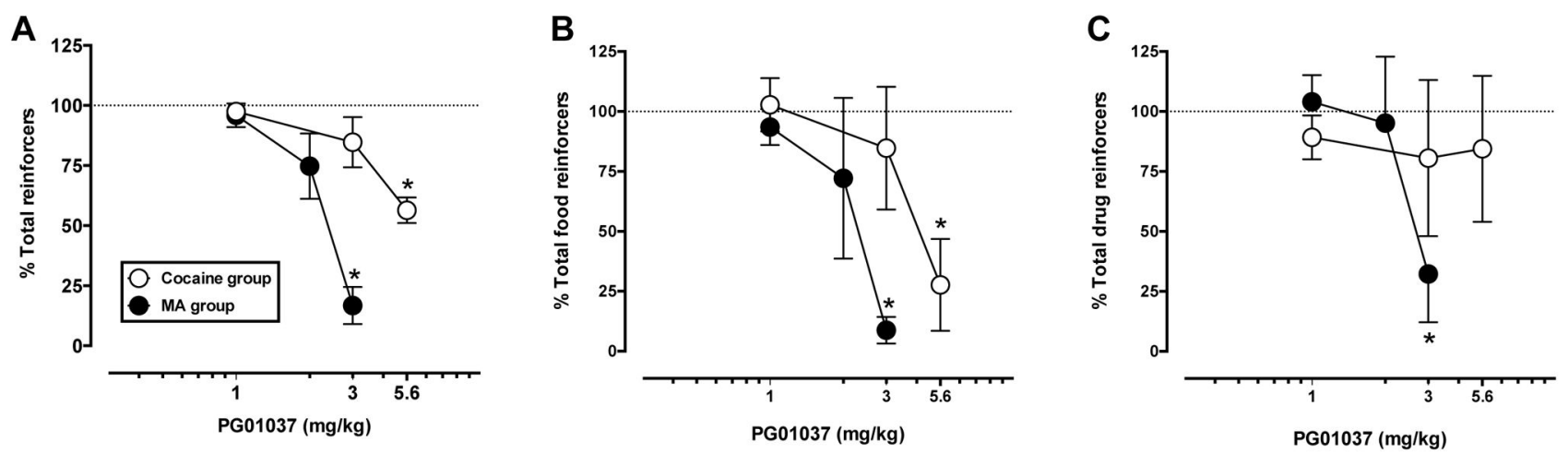

Figure 1.

Effects of acute (open symbols) and five-day (gray symbols) PG01037 (i.v.; best dose, see text) treatment on choice between cocaine and food (filled squares represent baseline) in rhesus monkeys $(n=4)$. Panel A ordinates: percent of reinforcers earned on the cocaineassociated switch (left) and percent of reinforces earned on food-associated switch (right). Panels B-D ordinates: number of respective reinforcer earned (maximum of 10 per component). Panels A-D abscissae: unit dose of cocaine in $\mathrm{mg} / \mathrm{kg}$ available as an alternative to a food pellet. Panel E ordinate: number of ratio requirements (choices) completed per session. Panel E abscissa: experimental end point. Panel F ordinate: overall session intake in $\mathrm{mg} / \mathrm{kg}$ cocaine. Panel F abscissa: treatment condition. Data represent mean \pm S.E.M. of 4, except Panel A, $n=3$ for percent choice in component 2 following acute treatment and component 3 for day 5 treatment, and $\mathrm{n}=2$ for percent choice in component 2 . *, $\mathrm{p}<0.05$ compared with baseline responding. 


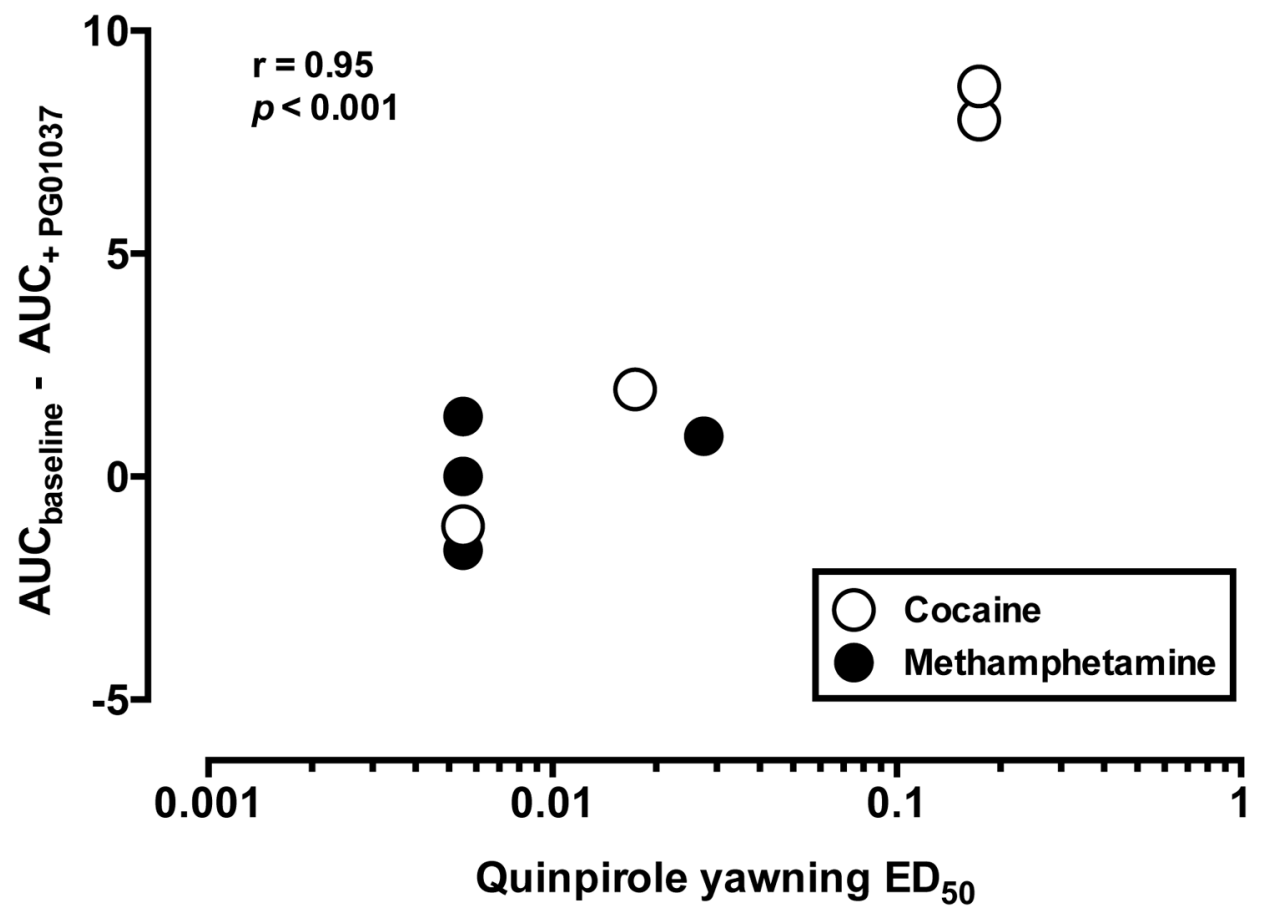

Figure 2.

Effects of acute (open symbols) and five-day (gray symbols) PG01037 (1.7 mg/kg, i.v.) treatment on choice between methamphetamine and food (filled squares represent baseline) in rhesus monkeys $(n=4)$. All details are as in Figure 1. Data represent mean \pm S.E.M. of 4 , except Panel A, n=3 for percent choice in components 1-3 following day 1 of treatment. For 5 day treatment, $\mathrm{n}=3$ for percent choice in components $1,2,4,5$ and $\mathrm{n}=2$ in component 3 . 


\section{Cocaine}
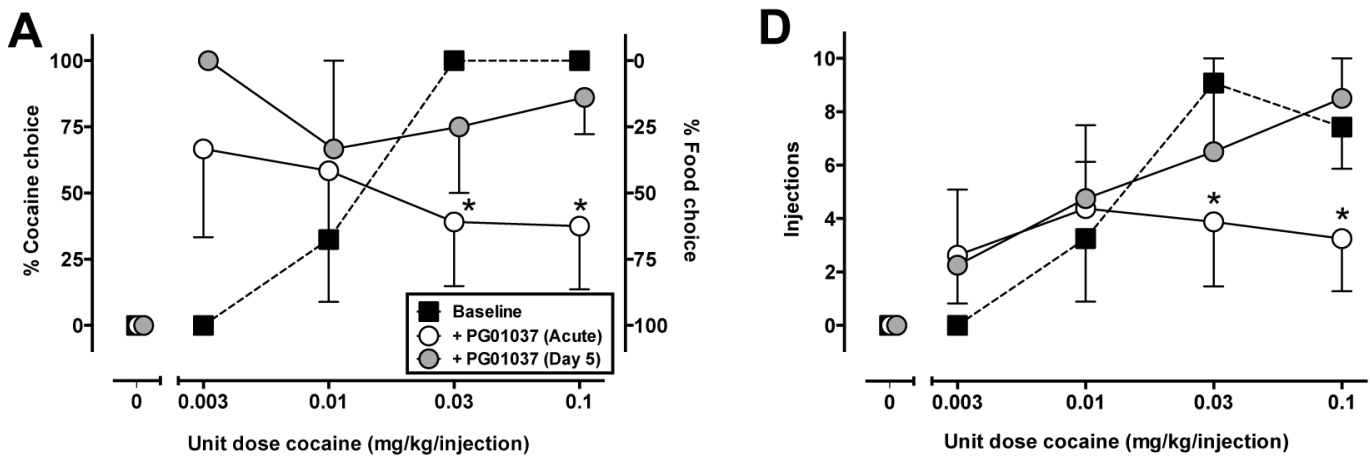

B

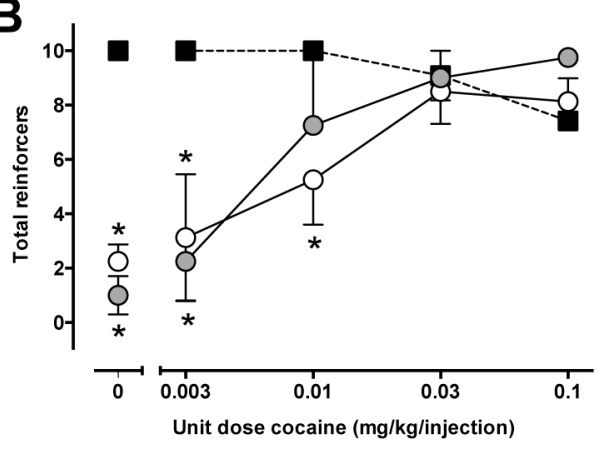

C

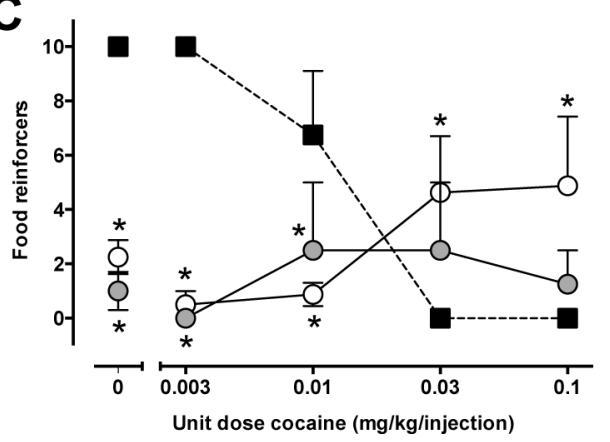

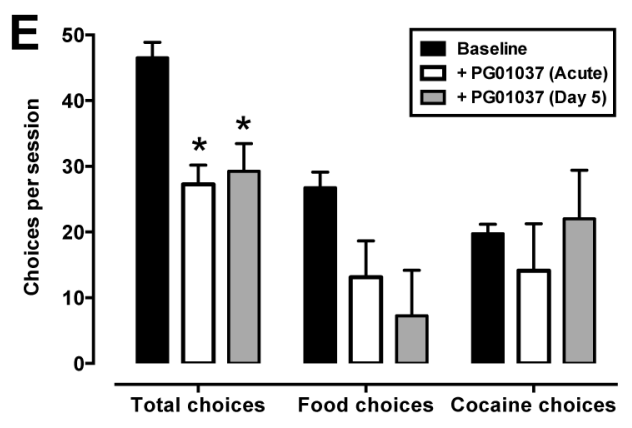

$\mathbf{F}$

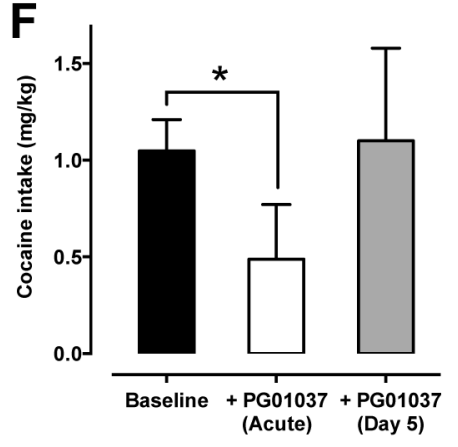

Figure 3.

Effects of PG01037 (1.0-5.6 mg/kg, i.v.) on percent total (A), food (B), and drug (C) reinforcers in monkeys ( $\mathrm{n}=4$ /group) choosing between food and cocaine (open symbols) or MA (closed symbols). Ordinates: percentage of respective baseline reinforcers earned. Abscissae: PG01037 dose (mg/kg). Data represent mean \pm S.E.M. *, p $<0.05, * *, p<0.01$, compared with baseline responding. 


\section{Methamphetamine}
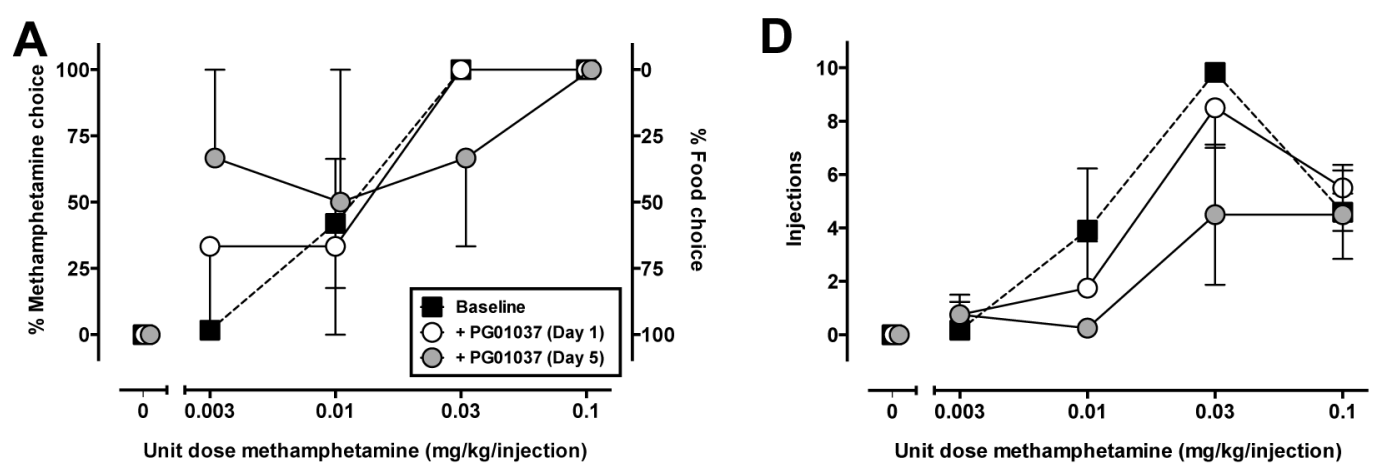

B

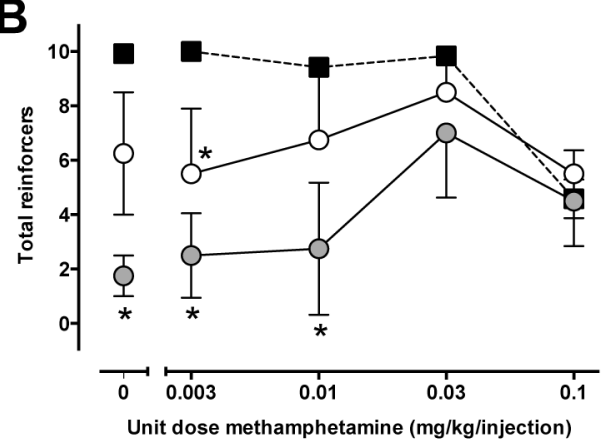

C

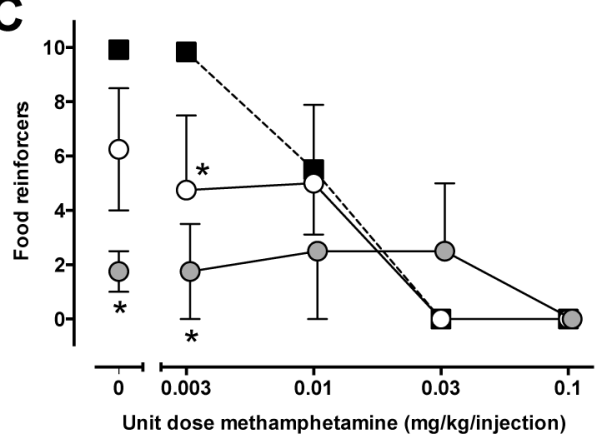

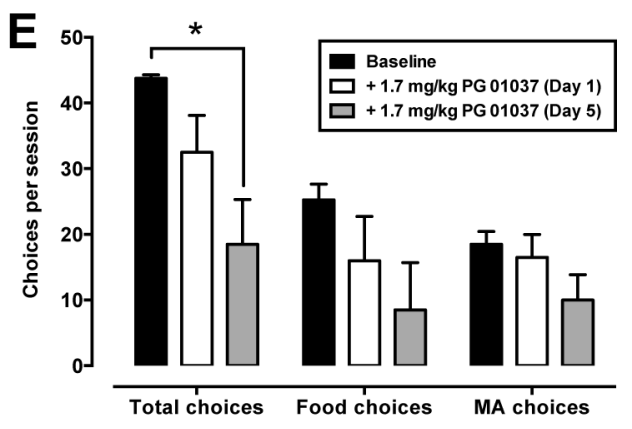

$\mathbf{F}$

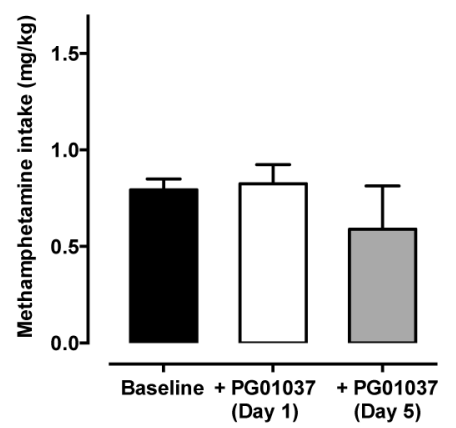

Figure 4.

Correlation between PG01037 effectiveness in reducing drug choice and sensitivity to quinpirole-elicited yawning. Ordinate: $\mathrm{AUC}_{\text {baseline }}-\mathrm{AUC}_{+} \mathrm{PG} 01037$. Absicissae: $\mathrm{ED}_{50}$ values in $\mathrm{mg} / \mathrm{kg}$ quinpirole. $(\mathrm{r}=0.95 ; \mathrm{p}<0.001)$. 


\section{TABLE 1}

Parameters and drug-history for individual subjects

\begin{tabular}{cccc}
\hline Subject & Food FR & Drug FR & Lifetime intake (mg/kg) \\
\hline Cocaine & & & \\
R-1661 & 30 & 10 & 422.15 \\
R-1688 & 50 & 40 & 419.3 \\
R-1689 & 10 & 100 & 274.55 \\
R-1692 & 30 & 100 & 225.14 \\
\hline MA & & & \\
R-1567 & 40 & 80 & 84.58 \\
R-1690 & 50 & 10 & 200.43 \\
R-1691 & 30 & 10 & 188.42 \\
R-1693 & 30 & 30 & 142.78 \\
\hline
\end{tabular}




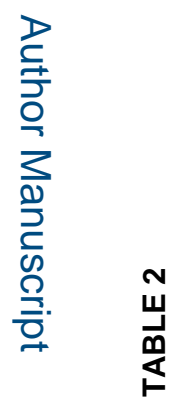

로을

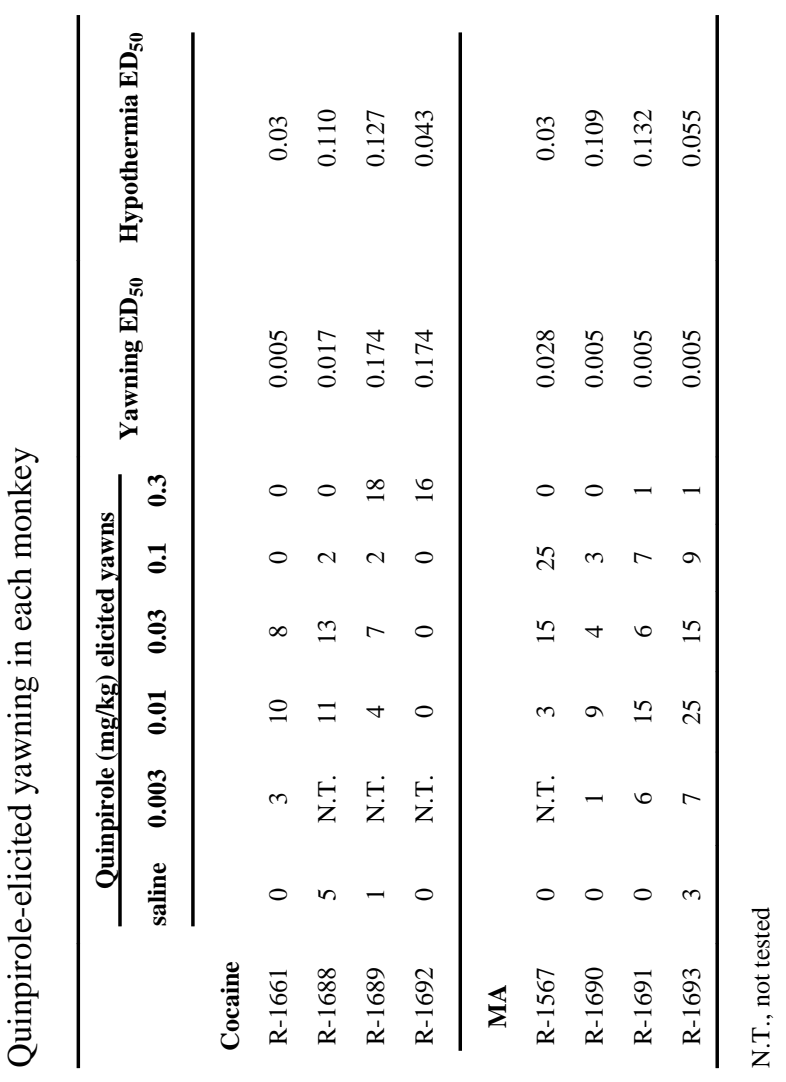

Neuropharmacology. Author manuscript; available in PMC 2016 May 01. 